Student Success

ISSN: 2205-0795

Volume 6, Issue 2, pp. 73-79

August 2015

\title{
Putting transition at the centre of whole-of-curriculum transformation
}

Marcus O'Donnell, Margaret Wallace, Anne Melano, Romy Lawson and Eeva Leinonen University of Wollongong, Australia

\section{Abstract*}

This paper describes the development of a model for institution-wide curriculum transformation at the University of Wollongong (UOW). Transition - a curriculum-integrated approach that enables a smooth, supported shift into and through higher education and a successful transition from the university to the world of work and lifelong learning - is one of three key principles at the heart of the UOW Curriculum Model. This paper focuses on transition as a whole-of-curriculum design principle and the way this principle informs the other elements of the UOW Curriculum Model. It aims to extend the concept of "transition pedagogy" developed by Kift and colleagues and to show how it has been used to inform our larger project of curriculum renewal.

*This 'New Idea and Emerging Initiative' was first presented at the 2015 STARS Conference in Melbourne, Australia in July 2015 and was selected by the Conference Committee as one of the toprated reports. The authors have kindly given their permission to have this report published in the conference issue of the Journal and it has undergone a further review by the editors to confirm it aligns with the Journal format.

Please cite this article as:

O’Donnell, M., Wallace, M., Melano, A., Lawson, R., \& Leinonen, E. (2015). Putting transition at the centre of whole-of-curriculum transformation. Student Success, 6(2), 73-79. doi: 10.5204/ssj.v6i2.295

Student Success: A journal exploring the experiences of students in tertiary education

(cc) Br $\mathrm{Br}$ This work is licensed under a Creative Commons Attribution 4.0 Licence. As an open access journal, articles are free to use, with proper attribution, in educational and other non-commercial settings. ISSN: 2205-0795 


\section{Curriculum Transformation Project}

The University of Wollongong's (UOW) Curriculum Transformation Project (CTP) is an ambitious plan to build on and enhance UOW's national and international reputation for top quality teaching and learning. It will be implemented in a phased approach that includes a holistic review of all UOW courses over the next four years (2015-2018) and the implementation of a Curriculum Model that comprises an agreed set of: Curriculum Themes, Curriculum Design Principles and Transformational Practices (Figure 1). recognises the interconnected nature of today's global challenges and the value multidisciplinary teams bring to the modern workplace. These principles link to the four curriculum themes that characterise the UOW student learning experience as one that is intellectually challenging, research/inquiry led, technology enriched with a real world focus. This rich learning experience is delivered through five transformational practices: a focused first year experience; integrated eportfolios; connections subjects which explore intercultural perspectives and take learners beyond their disciplines; hybrid learning which creatively matches a focused variety of face-to-

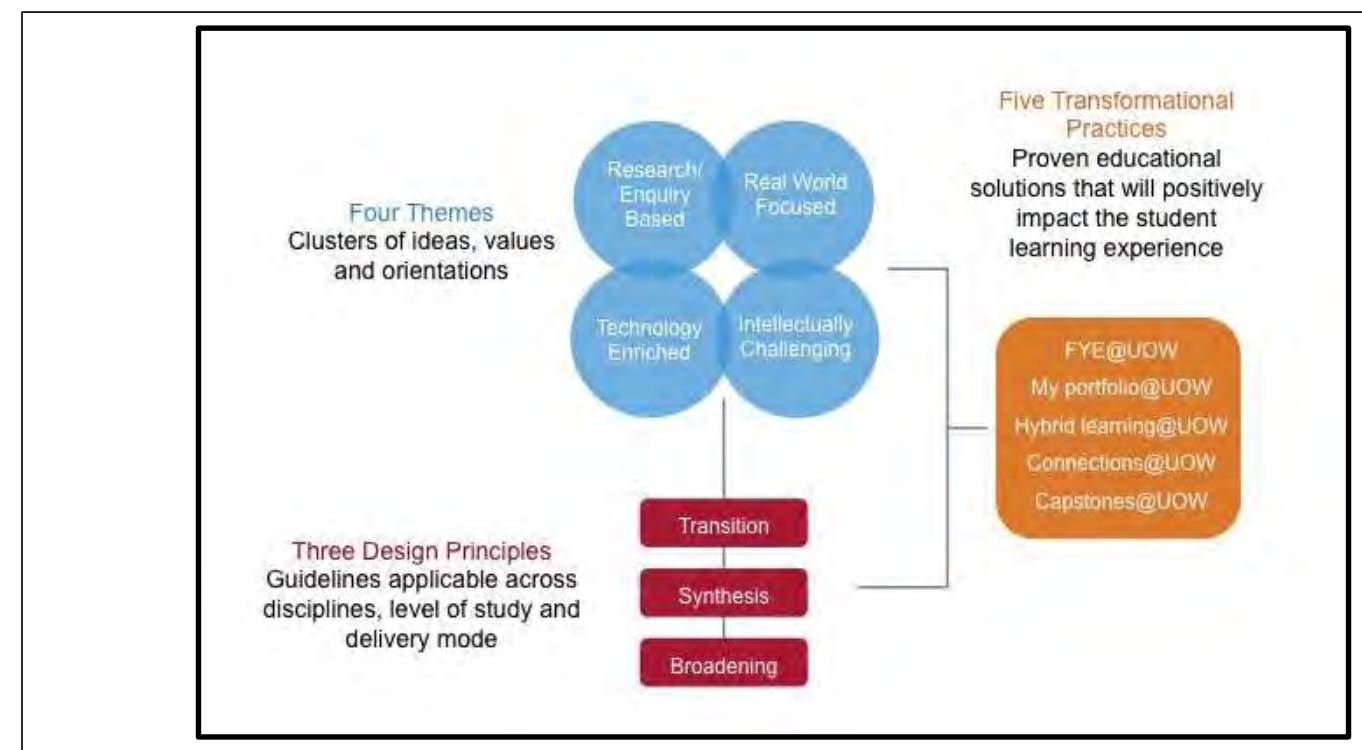

Figure 1: UOW Curriculum Model

At the heart of the UOW Curriculum Model are the three curriculum design principles: Transition: a supported shift into higher education and a successful transition from UOW to the world of work and lifelong learning; Synthesis: opportunities for students to share, synthesise and integrate their learning; and Broadening: a curriculum-integrated approach that compels a breadth of focus for learning beyond the student's primary area of study and face, online and blended learning opportunities; and a capstone experience for every course.

Three other elements are essential to this comprehensive approach to curriculum renewal. Firstly a set of assessment principles to support the curriculum model was developed through consultation across the university, with the guidance of two internationally recognised assessment experts: Professors Chris Rust from 
Oxford Brookes University and David Boud from the University of Technology, Sydney (UTS). Secondly, a co-curricular award program encourages student participation in a wide variety of projects throughout the university and acknowledges that students develop leadership, teamwork and problem-solving skills through a range of curricular and cocurricular experiences. Thirdly we recognize that academic staff are key collaborators in any process of curriculum renewal and that the UOW Curriculum Model will only succeed if it is supported by a cohesive and well-resourced Continuing Professional Development framework that builds staff capacity for curriculum development and best practice.

This paper focuses on a whole-of-curriculum design approach (Lawson 2013) and the way transition as a design principle informs all elements of the UOW Curriculum Model. It aims to extend the concept of "transition pedagogy" developed by Kift and colleagues (e.g.,Kift, Nelson, \& Clarke, 2010) and to show how it has been used to inform our larger project of curriculum renewal.

\section{Transition pedagogy}

Transition pedagogy is a set of principles and processes articulated by Kift and colleagues (Kift \& Nelson, 2005 Kift, 2009; Kift et al., 2010) as a framework for the development of an effective and supportive first year university experience. One of the distinguishing features of what Kift and colleagues describe as "third generation" approaches to first year transition and retention strategies, is that student learning is the focus - hence transition pedagogy. A strategic whole of institution suite of transition activities including curricular, co-curricular and administrative support functions are mediated through "the organizing device of curriculum" (Kift \& Nelson, 2005, p. 232).

Kift's (2009) six curriculum design principles for first year curriculum design - Transition,
Diversity, Design, Engagement, Assessment, Evaluation \& Monitoring - have garnered widespread support from colleagues and been adopted by a number of Australian institutions (Nelson, 2014, p. 8). Later work (Kift, Butler, McNamara, Brown, \& Treloar 2013) applied transition pedagogy to the final year capstone experience, linking the transition into university in first year with the transition out to the professional world in final year. This project identified a variation on the original set of principles introducing Integration \& Closure to emphasise the capstone experience.

Drawing on the constantly evolving and rich research on student transition, engagement and retention through the process of developing our curriculum model, we believe that several key additions are needed to better equip Kift's FYE principles as a whole-of-course framework. for transition pedagogy. These elements include:

\section{Narratives of Purpose}

The other widely cited model of student transition is Lizzio \& Wilson's Five Senses of Success (Lizzio, 2006; Lizzio \& Wilson, 2010) which outlines a model focused on building an academic culture which develops the student's sense of connection, capability, purpose, and resourcefulness. Drawing on their large-scale empirical research with commencing students, they particularly emphasise a sense of purpose as both predicting student satisfaction and persistence and as a protective factor that activates persistence in the face of difficulties (Lizzio \& Wilson, 2010). One of the ways they propose to enhance this sense of purpose is through sense-making narratives that build a sense of relevance:

Sense-making narratives: Students consistently comment on the lack of narrative in the way academics describe degree programs. Too often we talk to our student in a language of course lists and program structures at the 
expense of a unifying coherent student-centred narrative.

Relevance: Students, not surprisingly, comment that they are more likely to engage if they can see the relevance of things. Establishing personal relevance (rather than assuming an inherent appreciation of disciplinary relevance), particularly for younger students, is a necessary investment. Scaffolding motivation (until disciplinary socialization kicks in) is key to purpose building. (Lizzio \& Wilson $2010 \mathrm{p} \mathrm{4-5).}$

\section{Reflection}

In Kift's previous work on capstones (Kift, Field, \& Wells, 2008) Reflection was emphasized as a key principle whereas in the final set of principles this is encapsulated under engagement and assessment. Reflection has also been emphasized by other authors (Lawson, Kuilboer, Murphy \& Shircore, 2013; Shircore, Galloway, Corbett-Jarvis, \& Ryan, 2013) as a key integrating factor in a holistic transition pedagogy that moves from first year to final year experiences. An extensive body of literature supports the importance of reflection as an educational process and we believe it is an essential feature of pedagogical approaches that seek to scaffold a variety of transitions throughout a degree and build a sense of relevance and purpose over time.

\section{Assessment literacy}

In developing the assessment principles to support our new curriculum model, we drew heavily on the work of Chris Rust and colleagues (Price, Rust, O'Donovan, \& Handley, 2012; Rust, 2013) and their model of assessment literacy and David Boud's model of sustainable assessment for lifelong learning (Boud \& Falchikov, 2006). These models go beyond easy dichotomies of formative and summative assessment. They emphasise the development of an understanding of the processes and rationale of higher education assessment within the context of an evolving community of practice that includes students and staff - and the students development of skills and capacity to engage in increasingly sophisticated forms of assessment that ultimately result in a developed ability to self-assess.

\section{Capacity Building}

Assessment literacy is a key form of capacity building, and capacity building is a key element emphasized by both Lizzio and Wilson's (2010) Senses of Success model and Liz Thomas' (2012) major UK-wide study on student retention and success. Thomas emphasizes that capacity building must occur at three levels: building student capacity, building staff capacity and building institutional capacity. This is in line with Nelson's (2014) latest work which emphasises the development of an "Institutional Maturity Model" for ensuring student engagement, retention and success. Although the idea of capacity building is implicit in Kift's (2009) principle of Design which supports the "intentional integration and sequencing of knowledge, skills, and attitudes" (p. 41), we believe that both student and staff/institutional capacity building is so central that it ought to be made explicit.

With this research in mind, we have adapted and added to Kift's (2009) original FYE model to arrive at the following statement which better articulates a Transition Pedagogy for whole-ofcourse design.

Transition pedagogy is a set of practices mediated by an intentionally designed curriculum that enables a smooth, supported shift into higher education and a successful transition from university to the world of work and lifelong learning. Transition pedagogy mediates and supports transition as a process that occurs over time and is designed around the following principles. It: 
- $\quad$ recognises and facilitates the needs of diverse student cohorts;

- is facilitated by focused capacity building opportunities for both staff and students;

- introduces and develops knowledge, skills, and attitudes through a linked sequence of learning opportunities;

- builds engagement and belonging through active and collaborative learning;

- builds assessment literacy that develops student's capacity to selfassess and engage in sustainable lifelong learning;

- $\quad$ establishes closure at key points of the learning journey to allow students to integrate and synthesise knowledge, skills, and attitudes;

- facilitates reflection that allows students to recognise, assess and integrate their capabilities and performance;

- $\quad$ creates transparent sense-making narratives through negotiating clear objectives and learning processes and making explicit links between a range of learning activities to build a sense of purpose;

- creates integrated pathways between curricular and co-curricular learning opportunities and supports;

- $\quad$ integrates a variety of monitoring processes that include subject-based formative feedback and subject and course-based data analytics to enable tracking of individual student experience and tailoring of appropriate support; and
- engages in a rigorous cycle of evaluation and renewal that measures effectiveness of the curriculum and informs its iterative redesign. 


\section{Embedding transition pedagogy}

These principles of transition pedagogy inform the implementation of UOW Curriculum Model's transformational practices. The following table indicates the connections.

Table 1: UOW Curriculum Model - transformational practices

\begin{tabular}{|c|c|}
\hline $\begin{array}{l}\text { First Year } \\
\text { Experience }\end{array}$ & $\begin{array}{l}\text { Although the UOW Curriculum Model emphasizes transition as a whole-of-course principle, } \\
\text { it also recognizes the critical role that the first year experience plays in capacity building and } \\
\text { establishing initial student narratives of purpose. "Six First Year Firsts: Critical Curriculum } \\
\text { Points" is a UOW model which points to six critical moments that can make a difference to } \\
\text { students FYE building capacity in a strategic sequenced way: first subject, first week, first } \\
\text { class, first assessment, first feedback, first final. (Harden-Thew \& Dean 2015). Six First Year } \\
\text { Firsts begins the task of developing assessment literacy critical to all academic success and } \\
\text { lifelong learning. }\end{array}$ \\
\hline My Portfolio & $\begin{array}{l}\text { The integration of e-portfolios into all courses is a central plank in a transition pedagogy that } \\
\text { enables student capacity (Lawson et al., 2013). It provides an opportunity for students to create } \\
\text { sensemaking narratives that explicitly address their transition experiences. It allows students } \\
\text { to understand and interrogate the linked sequence of learning experiences, tasks and } \\
\text { interactions. Through reflecting on their own learning, they also develop assessment } \\
\text { literacies - developing their ability to self-assess and recognize their evolving capacities- } \\
\text { giving them confidence to showcase their skills and knowledge as they transition out into the } \\
\text { world of work. Portfolio exercises can become useful markers of experience when employed } \\
\text { at key points in the course such as year-end transition points to bring closure to particular } \\
\text { points in student development and prepare students for the next stage of the learning journey. }\end{array}$ \\
\hline $\begin{array}{l}\text { Hybrid } \\
\text { Learning }\end{array}$ & $\begin{array}{l}\text { Choosing a variety of learning experiences recognizes the diversity of student experience and } \\
\text { caters to and develops different learning styles. Both facilitated and online collaborative } \\
\text { learning enhances student engagement and belonging but a hybrid approach that combines } \\
\text { the two has the potential, when facilitated skillfully, to create deep communities of practice } \\
\text { that connect students across space and time. }\end{array}$ \\
\hline $\begin{array}{l}\text { Connections } \\
\text { Subjects }\end{array}$ & $\begin{array}{l}\text { Investigations of Transition Pedagogy have usually conceived of transition as an experience } \\
\text { of movement across the lifecycle of the degree program and out into the world but it can also } \\
\text { be conceived as a transition across disciplinary boundaries and across cultural experiences. } \\
\text { UOW Connections subjects are designed to enhance these other forms of student transition. } \\
\text { Acknowledging diverse cultural perspectives also acknowledges and affirms the diversity of } \\
\text { the student cohort. }\end{array}$ \\
\hline $\begin{array}{l}\text { Capstone } \\
\text { Experience }\end{array}$ & $\begin{array}{l}\text { Just as a capacity building focused first year experience is critical to set students on the path } \\
\text { of academic success, capstone experiences are critical to build capacity for the world of work } \\
\text { and bring closure to the university learning journey. }\end{array}$ \\
\hline
\end{tabular}




\section{References}

Boud, D., \& Falchikov, N. (2006). Aligning assessment with long-term learning. Assessment \& Evaluation in Higher Education, 31(4), 399-413. doi: $10.1080 / 02602930600679050$

Harden-Thew, K. \& Dean, B. (2015 July). Translating Kift's first year curriculum principles into the classroom: Focusing on Six First Year Firsts. Paper presented at STARS: Student, Transition, Achievement, Retention, \& Success Conference, Melbourne, Australia, 1-4 July. Retrieved from: http://www.unistars.org/papers/STARS2015/08B.p df

Kift, S. (2009). Articulating a transition pedagogy to scaffold and to enhance the first year student learning experience in Australian higher education. Final Report for ALTC Senior Fellowship Program. Sydney, Australia: Australian Learning and Teaching Council. Retrieved from http://fyhe.com.au/wpcontent/uploads/2012/10/Kift-Sally-ALTC-SeniorFellowship-Report-Sep-092.pdf

Kift, S., Butler, D., McNamara, J., Brown, C., \& Treloar, C. (2013). Capstone experiences principles and commentary. Report prepared for the Office of Learning and Teaching. Sydney, Australia: Office of Learning and Teaching. Retrieved from http://www.olt.gov.au/resource-curriculumrenewal-legal-education.

Kift, S., Field, R., \& Wells, I. (2008). Promoting sustainable professional futures for law graduates through curriculum renewal in legal education: A final year experience (FYE2). eLaw Journal, 15(2), 145-158.

Kift, S. \& Nelson, K. (2005). Beyond curriculum reform: Embedding the transition experience. In A. Brew, \& C. Asmar (Eds.), Proceedings of HERDSA 28, pp. 225235. The University of Sydney: Australia. Retrieved from http://www.herdsa.org.au/wpcontent/uploads/conference/2005/papers/kift.pdf

Kift, S., Nelson, K., \& Clarke, J. (2010), Transition pedagogy: A third generation approach to FYE: A case study of policy and practice for the higher education sector. The International Journal of the First Year in Higher Education, 1(1), 1-20. doi: 10.5204/intjfyhe.v1i1.13

Lawson, R., (2015). Curriculum design for assuring learning - leading the way. OLT National Teaching Fellowship Final Report. Sydney: Office for Learning and Teaching. Retrieved from: http://www.olt.gov.au/resource-curriculum-designassuring-learning-leading-way-2015

Lawson, R., Kuilboer, A., Murphy, L., \& Shircore, M. (2013, July). Jack Reacher's Rules - always keep your exit in view: Using an ePortfolio from day 1 to foster work ready students. Paper presented at the $16^{\text {th }}$ International First Year in Higher Education
Conference, Wellington, New Zealand. Retrieved from http://fyhe.com.au/past papers/papers13/10F.pdf

Lizzio, A. (2006). Designing an orientation and transition strategy for commencing students, First Year Experience Project. Brisbane, Australia: Retrieved from

http://www.griffith.edu.au/ data/assets/pdf file/0 008/51875/Alfs-5-Senors-Paper-FYE-Project,-2006.

Lizzio, A., \& Wilson, K. (2010, June). Strengthening commencing students' sense of purpose: Integrating theory and practice. Paper presented at the, 13th Pacific Rim First Year in Higher Education Conference. Adelaide: Australia. Retrieved from http://www.fyhe.com.au/past papers/papers10/co ntent/pdf/12D.pdf

Nelson, K. (2014). The first year in higher education - Where to from here? The International Journal of the First Year in Higher Education, 5(2), 1-20. doi: 10.5204/intjfyhe.v5i2.243

Price, M., Rust, R., O'Donovan, B.; \& Handley, K. (2012). Assessment literacy: The foundation for improving student learning. Oxford, UK: The Oxford Centre for Staff and Learning Development.

Rust, C. (2013, August). The international state of research on assessment \& examinations in higher education. Symposion zur Prufüngsforschung (Symposium on Assessment Research) University of Hamburg, Germany. Retrieved from https://www.academia.edu/4305205/The internati onal state of research on assessment and examinat ions in Higher Education

Shircore, M., Galloway, K. Corbett-Jarvis, N. \& Ryan, D. (2013). From the first year to the final year experience: Embedding reflection for work integrated learning in a holistic curriculum framework. A Practice Report. The International Journal of the First Year in Higher Education, 4(1), 125-133. doi: 10.5204/intjfyhe.v4i1.158

Thomas, L. (2012). Building student engagement and belonging in higher education at a time of change. London, UK: Paul Hamlyn Foundation. 